\title{
ARTICLES
}

\section{KNOWLEDGE OF SCHOOL STUDENTS REGARDING ROAD SAFETY}

\section{Mr. Ashu Kesar*| Dr. Darshan Sohi**}

* Research Scholar in Himalayan University, Itanagar, Arunachal Pradesh, India.

**Principal, Chief Khalsa Diwan International Nursing College, Amritsar, Punjab, India. DOI: http://doi.org/10.47211/tg.2020.v07i03.015

\section{ABSTRACT:}

Road safety is the methods and measures for reducing the risk of person using the road network for being killed or seriously injured. Children are nation's biggest asset. Every year 1, 40,590 people die due to road traffic accidents. Road safety is the necessity of each human being to protect oneself and other's life because there is day to day increase the number of the traffic and that leads road traffic accidents. As adults, we are responsible for young children's safety on roads. With the help of creating awareness among people that can prevent road traffic accidents. The aim of the study is to assess the knowledge of school students regarding road safety. The study adopted a pre - experimental research design to assess the knowledge of students regarding road safety in selected senior secondary school of Amritsar. The sample size was 500 school students. Convenient Sampling technique was used. The tool was two sections, section 1 consists of a self-structured demographic questionnaire and section 2 consists of a self-structured knowledge questionnaire. The result indicates that out of 500 samples, Pre- Test the majority 5.6\% had very good knowledge, 17.2\% had Good knowledge, 53.8\% of sample had Average knowledge, 23.4\% had poor knowledge, Post- Test the majority 46.6\% had very good knowledge, 45.6\% had Good knowledge, 7.8\% of sample had Average knowledge, and 0\% had poor knowledge.

Key Words: Road safety, knowledge, school students.

\section{ABOUT AUTHORS:}

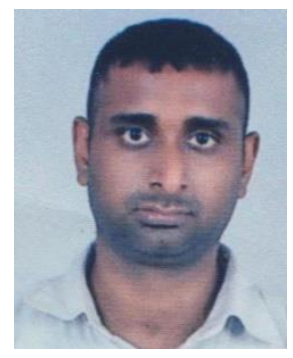

Author, Mr. Ashu Kesar is a Ph.D. Scholar at Himalayan University, Itanagar, Arunachal Pradesh, India. He has attended various National and International conferences and given extension lectures.

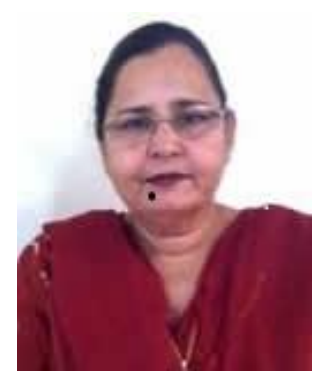

Author, Dr. Darshan Sohi is Principal at Chief Khalsa Diwan International Nursing College, Amritsar, Punjab, India. She has vast research experience. 


\section{INTRODUCTION}

Children are one of important vulnerable group in our society. Adolescent is defined as the period from the onset of puberty to the termination of physical growth and sexual maturity, and achievement of adult characteristics. Various habits in adolescents related to health which affect directly and indirectly to their health. In adolescent males show more aggressive behavior than females. Every child has different temperament profile and has high activity level. Their main developmental characteristics like natural curiosity to explore environment, desire to assert self and challenge to rules, desire for peer approval and acceptance, have less ability to recognize threat or danger, pre occupied with abstract thinking and loses sight of reality. The common cause of death among school children are road traffic injuries either they are on foot or on vehicle. In India, that is one of the major causes of injuries or death as compared to terrorism to natural death.

\section{LITERATURE REVIEW}

Agarwal P, Mehrotra D, Agarwal R, Kumar S, Pandey R. (2016) conducted a retrospective study on 1000 patients in Uttar Pradesh, India, based upon a systematic computer assisted database search from March 2015 to March 2016. This study revealed that male female ratio about accidents or injuries were $8: 1$ and in such data $45.1 \%$ of zygomatic and $44.4 \%$ mandibular fractures observed. This study concluded that awareness about preventive measures and safety rules followed by the road users controls these injuries and these rules should reinforced strictly by law or legislation.

Kadur Praveen B., Madhukar.S, Darshan Bevoor, Gurupada K. (2015) conducted a pre experimental study on 60 subjects of higher primary school children at Dharma rathnakara Rajanahalli Rama shetty School, Davangere, India. This study revealed that posttest knowledge score regarding road safety were higher $80.7 \%$ as compared to pretest $64.7 \%$. This study concluded that health education and training about road safety increases the knowledge of school students and they follow rules while travelling on roads.

Shah Aharnish, Jarwan Bhavesh (2014) conducted a cross sectional observational study on 150 patients in emergency department of Vaddilal Sarabhai hospital at Ahmedabad city, India. This study revealed that patient's age between 11 to 50 years and $41 \%$ were passengers and pedestrians who were affected by accidents. Main causes about these injuries were malpractice of traffic rules, $20 \%$ driving without license, $10 \%$ of population used mobile phones while driving, $26 \%$ not using head lights at night time, $80 \%$ not wearing seat belts, $91 \%$ not using helmets. Immediate care given at that time period which had $38 \%$ dressing, $27.33 \%$ laceration repair, $24 \%$ splinting and $10 \%$ crash intubation etc. This study concluded that immediate emergency care should save the life of injured patients.

\section{METHODOLOGY:}

In this study, quantitative research approach was used. The research design adopted in this study was preexperimental research design. The study was conducted at selected senior secondary school in Amritsar, Punjab. A total of 500 samples were selected by convenient sampling technique. Structured knowledge questionnaire was used as research tool. This tool was consisted two parts such as demographic variables and structured knowledge questionnaire. Data was analyzed by descriptive and inferential statistics. The knowledge of students was enhanced with information booklet regarding road safety which covers main rules of road safety, about traffic lights, signs, and signals etc.

Data collection procedure:

$>$ Prior a written permission was obtained from the principal of selected senior secondary school, Amritsar.

$>$ Non probability convenient sampling technique was used to select the sample. Subjects who met the set criterion were included in the study.

$>$ School students were personally contacted by the investigator. They were explained about the study. Their informed consent was taken before enrolling them in the present study.

$>$ After getting consent that day self-structured knowledge questionnaire was distributed to the sample to assess the knowledge of school students regarding road safety.

$>$ About 30 minutes were given to the samples to complete the questionnaire.

$>$ After collecting data from each sample, information booklet on road safety was distributed to individual sample.

\section{RESULTS \& DISCUSSION:}

The design used in this study was non experimental that was descriptive in nature. The conceptual framework adapted for this study was based on Rosen stock's (1974) and Becker's health belief model (1975). The participants 


\section{ARTICLES}

were selected by non-probability convenient sampling technique and were analyzed with descriptive and inferential statistics.

Major findings of research study:

Distribution of demographic characteristics of samples:

Higher percentage of school students (53.4\%) were in age group 13-15 years.

Majority $(77.8 \%)$ of school students were males.

Majority (45\%) of school students were in 10th class

Most of students (59\%) had labour occupation of parents.

Majority $(60.6 \%)$ of school student's education of mother were primary education.

Majority (47.2\%) of school student's education of father were primary education

Most of (61.2\%) family income below rs.10, 000 per month.

Most of (47\%) were from urban area.

$53 \%$ school students were coming to school by school bus.

$43.2 \%$ school students were receiving information about road safety from their parents.

Pretest Knowledge score of school students on selected senior secondary school regarding road safety: The present study results confirm that majority $5.6 \%$ had v. good knowledge, $17.2 \%$ had good knowledge $53.8 \%$ had average knowledge and $23.4 \%$ had poor knowledge regarding road safety.

Posttest Knowledge score of school students on selected senior secondary school regarding road safety: The present study results confirm that majority $46 . .6 \%$ had v. good knowledge, $45.6 \%$ had good knowledge $7.8 \%$ had average knowledge and $\%$ had poor knowledge regarding road safety.

Association of knowledge score with selected demographic variables: There were highly significant association of knowledge with demographic variables as calculated values with age $x^{2}=10.94$, with $\operatorname{sex} x^{2}=6.68$, with residential place $x^{2}=6.72$ and with source of information then $x^{2}=12.898$. Whereas demographic variables family income, parent's education and mode of transportation shows no association with knowledge of students regarding road safety.

\section{CONCLUSION:}

Road safety is very important for each individual and knowledge regarding road safety measures will help the school students to save the life and prevent from life threatening conditions. Knowledge regarding road safety protects the child from being injured or disabled. Students must have knowledge regarding road safety such as how to cross road, traffic lights, indicators, road safety measures etc. That prevents complications occur due to road traffic accidents. The focus of the study to assess the knowledge regarding road safety among school students in selected senior secondary school in Amritsar, Punjab. It is concluded that health is very important for each individual and knowledge regarding road safety will help the school students to restore the health and prevent from life threatening conditions.

\section{REFERENCES:}

1. Agarwal P, Mehrotra D, Agarwal R, Kumar S, Pandey R. Patterns of Maxillofacial Fractures in Uttar Pradesh, India. Craniomaxillofacial Trauma Reconstruction.2017Mar; 10(1):48-55. Available from: https://www.ncbi.nlm. nih.gov/pubmed/28210408

2. Praveen B. Kadur, Madhukar.S, Darshan Bevoor, Gurupada K. Effectiveness of Structured Teaching Program on knowledge regarding road safety measures among Higher Primary School Children at DRR School, Davangere. Journal of Educational Research \& Medical Teacher. 2015; 3(1):22-23.

3. Shah Aharnish, Jarwani Bhavesh. Study of patients of road traffic accidents arriving in emergency department [ED] of V.S hospital at Ahmedabad city, single center pilot study. NHL Journal of Medical Sciences. 2014 July; 3(2) 23-26. Available from: http://www.nhlmmc.edu.in/document/nhljms\% 20Volume. $3 \%$ 20lssue .2/23-26.pdf 